\title{
Preparation and Properties of Phosphate Glasses and Glass-Ceramics Containing Large Amounts of Titanium ( $\mathbb{N}$ )
}

\author{
Akira KISHIOKA, Yuki MIYAZAWA, Kiyoshi ITATANI, F. Scott HOWELL and Makio KINOSHITA \\ Department of Chemistry, Faculty of Science and Technology, Sophia University, 7-1, Kioi-cho, Chiyoda-ku, Tokyo 102
}

\author{
多量のチタン $(\mathbb{N})$ を含有するリン酸塩ガラス及びガラスセラミックスの製造と性質 \\ 岸岡 昭・宮沢結樹・板谷清司・F. Scott Howell・木下眞喜雄 \\ 上智大学理工学部化学科, 102 東京都干代田区紀尾井町 7-1
}

[Received September 6, 1993; Accepted November 16, 1993]

\begin{abstract}
Phosphate glasses containing very large amounts of $\mathrm{TiO}_{2}$ have been prepared in the compositions of $\left(3 \mathrm{Na}_{2} \mathrm{O} \cdot 67 \mathrm{TiO}_{2} \cdot 30 \mathrm{P}_{2} \mathrm{O}_{5}\right)+5 \mathrm{SiO}_{2}(\mathrm{~mol} \%)$ (Glass-1) and $\left(3 \mathrm{Na}_{2} \mathrm{O} \cdot 72 \mathrm{TiO}_{2} \cdot 25 \mathrm{P}_{2} \mathrm{O}_{5}\right)+5 \mathrm{SiO}_{2}(\mathrm{~mol} \%)$ (Glass-2). The thermal expansion coefficient $(\alpha)$ from 30 to $600^{\circ} \mathrm{C}$ were $7.7 \times 10^{-6}{ }^{\circ} \mathrm{C}^{-1}$ and $6.9 \times 10^{-6}{ }^{\circ} \mathrm{C}^{-1}$, respectively. The glass-ceramics prepared by heating Glass -1 at temperatures in $50^{\circ} \mathrm{C}$ intervals from 800 to $1000^{\circ} \mathrm{C}$ for $30 \mathrm{~h}$ had $\alpha=0.7-2.2 \times 10^{-6}{ }^{\circ} \mathrm{C}^{-1}$ and glass-ceramics prepared by heating Glass-2 at various temperatures from 900 to $1100^{\circ} \mathrm{C}$ for $30 \mathrm{~h}$ had $\alpha=1.6-8.4 \times 10^{-7}{ }^{\circ} \mathrm{C}^{-1}$ in the same temperature range. The bending strengths of the glass-ceramics from Glass-1 were larger than those from Glass-2. The low thermal expansions of these glass-ceramics were attributed to $\mathrm{NaTi}_{2}\left(\mathrm{PO}_{4}\right)_{3}$-like phase, $\mathrm{TiO}_{2}$ and $(\mathrm{TiO}){ }_{2} \mathrm{P}_{2} \mathrm{O}_{7}$ produced by crystallization, and the bending strengths were greatly influenced by the crystalline phases. The $\mathrm{NaTi}_{2}\left(\mathrm{PO}_{4}\right)_{3}{ }^{-}$ like phase seems to be a solid solution of $\mathrm{NaTi}_{2}\left(\mathrm{PO}_{4}\right)_{3}$ and $\mathrm{Si}^{4+}, \mathrm{Na}_{1+x} \mathrm{Ti}_{2} \mathrm{P}_{3-x}, \mathrm{Si}_{x} \mathrm{O}_{12}$, as judged from the differences between the lattice parameters of this phase and those of $\mathrm{NaTi}_{2}\left(\mathrm{PO}_{4}\right)_{3}$.
\end{abstract}

Key-words : Glass, Phosphate glass, Titanate glass, Glassceramics, Crystallized glass, Low thermal expansion, Thermal expansion coefficient

\section{Introduction}

The addition of $\mathrm{TiO}_{2}$ to phosphate glass contributes to the stabilization of the glass structure, as similar additions to $\mathrm{Al}_{2} \mathrm{O}_{3}$ and $\mathrm{B}_{2} \mathrm{O}_{3}$ do. One of the authors has reported that glasses containing large amounts of $\mathrm{TiO}_{2}$ can be prepared in compositions with lower than $50 \mathrm{~mol} \%$ of $\mathrm{P}_{2} \mathrm{O}_{5}$ in $\mathrm{M}_{2} \mathrm{O}-\mathrm{TiO}_{2}-$ $\mathrm{P}_{2} \mathrm{O}_{5}\left(\mathrm{M}^{\mathrm{I}}=\mathrm{Li}, \mathrm{Na}\right.$ and $\left.\mathrm{K}\right)$ and $\mathrm{M}^{\mathrm{II}} \mathrm{O}-\mathrm{TiO}_{2}-\mathrm{P}_{2} \mathrm{O}_{5}\left(\mathrm{M}^{\mathrm{II}}\right.$ $=\mathrm{Mg}$, $\mathrm{Ca}$ and $\mathrm{Ba}$ ) systems. ${ }^{1)}$,2) These glasses are excellent in chemical durability. ${ }^{1)}$ The double phosphates such as $\mathrm{LiTi}_{2}\left(\mathrm{PO}_{4}\right)_{3}, \mathrm{NaTi}_{2}\left(\mathrm{PO}_{4}\right)_{3}$ and $\mathrm{CaTi}_{4}$ $\left(\mathrm{PO}_{4}\right)_{6}$ etc. are formed as main crystalline phases by crystallization.3)-6) Such compounds show a low thermal expansion coefficient and/or an ionic conductivity. ${ }^{7)-13)}$ But without additions the powders of these double phosphates do not yield sintered materials with sufficient strength. Hanada et al. have reported that the amorphous film in the system $\mathrm{TiO}_{2}-$
$\mathrm{SiO}_{2}$ exhibits a decrease in thermal expansion coefficient up to about $15 \mathrm{~mol} \%$ of $\mathrm{TiO}_{2} .{ }^{14)}$ Therefore, the phosphate glasses and glass-ceramics containing large amounts of $\mathrm{TiO}_{2}$ are also interesting as low thermal expansion materials.

In this study, the glasses with large amounts of $\mathrm{TiO}_{2}$ were prepared by addition of small quantities of $\mathrm{SiO}_{2}$ to $\mathrm{Na}_{2} \mathrm{O}-\mathrm{TiO}_{2}-\mathrm{P}_{2} \mathrm{O}_{5}$ system with low $\mathrm{Na}_{2} \mathrm{O}$ content. The crystalline phases in devitrified products of these glasses were investigated by X-ray powder diffractometry. In addition, the relation between the thermal expansion values of crystallized glasses and the crystalline phases has been considered. Such data allowed the authors to prepare new titanatephosphate glass-ceramics with a very low thermal expansion coefficient.

\section{Experimental}

\subsection{Preparation of glasses}

Based on the results of fusing and quenching for the nine kinds of samples with different compositions, two kinds of glasses with the compositions of $\left(3 \mathrm{Na}_{2} \mathrm{O} \cdot 67 \mathrm{TiO}_{2} \cdot 30 \mathrm{P}_{2} \mathrm{O}_{5}\right)+5 \mathrm{SiO}_{2}(\mathrm{~mol} \%)$ (Glass-1) and $\left(3 \mathrm{Na}_{2} \mathrm{O} \cdot 72 \mathrm{TiO}_{2} \cdot 25 \mathrm{P}_{2} \mathrm{O}_{5}\right)+5 \mathrm{SiO}_{2}(\mathrm{~mol} \%) \quad(\mathrm{G}-$ lass-2) were prepared. The materials used were reagent grade chemicals of $\mathrm{NaH}_{2} \mathrm{PO}_{4}, \mathrm{TiO}_{2}, \mathrm{SiO}_{2}$ and $\mathrm{H}_{3} \mathrm{PO}_{4}(85 \%)$. A batch (15 g) obtained by mixing the necessary amounts of these chemicals was placed in a platinum evaporating dish and heated in an electric furnace. After the sample had been preheated up to $300^{\circ} \mathrm{C}$ at a heating rate of $10^{\circ} \mathrm{C} \cdot \mathrm{h}^{-1}$ and further from $300^{\circ} \mathrm{C}$ up to $500^{\circ} \mathrm{C}$ at $20^{\circ} \mathrm{C} \cdot \mathrm{h}^{-1}$, it was kept at $500^{\circ} \mathrm{C}$ for $3 \mathrm{~h}$. Then, the temperature was raised further to $1450^{\circ} \mathrm{C}$ over a $2 \mathrm{~h}$ period and kept at this temperature for $1 \mathrm{~h}$. The melt of each batch was poured out in a graphite mold (either $0.5 \mathrm{~cm}$ inside diameter $\times 1.2 \mathrm{~cm}$ or $3 \times 3 \times 1.5 \mathrm{~cm})$ and annealed.

2.2 Characterization and crystallization of glasses

The thermal expansion coefficients $(\alpha)$ in the range from 30 to $600^{\circ} \mathrm{C}$ and the glass transition temperatures $\left(T_{\mathrm{g}}\right)$ of the glasses were determined from the thermal expansion curves of glass specimens $5 \times 5 \times 3 \mathrm{~mm}$ in size. The density $(\rho)$ was measured 
by the Archimedes method. The powdered glasses were subjected to differential thermal analysis (DTA). The crystallization of the bulk glasses was carried out by heating rectangular glass bars of $5 \times 5 \times 25 \mathrm{~mm}$ in size at various temperatures in intervals of $50^{\circ} \mathrm{C}$ from 800 to $1100^{\circ} \mathrm{C}$ for $30 \mathrm{~h}$. The $800^{\circ} \mathrm{C}$ is close to the termination temperature of exothermic effects in the DTA for the glasses (Fig. 2). In order to prepare the stable glass-ceramics on heating, the glasses were subjected to heating at $800^{\circ} \mathrm{C}$ or higher for a long time. The pulverized glass-ceramics were examined by X-ray powder diffractometry (XRD). The identifications of crystalline phases were carried out by reference to the JCPDS cards; then the desired compounds were prepared separately. The solid solution of $\mathrm{NaTi}_{2}\left(\mathrm{PO}_{4}\right)_{3}$ and $\mathrm{Si}^{4+}$ formed by heating was confirmed by comparing the lattice parameters calculated for this compound with those of $\left.\mathrm{NaTi}_{2}\left(\mathrm{PO}_{4}\right)_{3}{ }^{15}\right)$ For the glass-ceramics obtained by heating at these temperatures, the thermal expansion coefficients in the range from 30 to $600^{\circ} \mathrm{C}$ were determined and the bending strengths were measured. The fracture surfaces of these glass-ceramics were also observed by scanning electron microscopy (SEM).

\subsection{Analyzers and analysis conditions}

The following analyzers were used, under the conditions given in the parentheses.

High-temperature type differential thermobalance, Rigaku Denki TG-DTA (quantity of the sample: approximately $70 \mathrm{mg}$ of powdered glass under 74 $\mu \mathrm{m}$; the standard sample: $\alpha-\mathrm{Al}_{2} \mathrm{O}_{3}$; heating rate: $10^{\circ} \mathrm{C} \cdot \min ^{-1}$; heated in air; DTA sensitivity: \pm 100 $\mu \mathrm{V})$.

Powder X-ray diffractometer, Rigaku Denki RAD- II A Model ( $\mathrm{Cu} \mathrm{K} \alpha$, applied voltage: $35 \mathrm{kV}$; tube current: $22.5 \mathrm{~mA}$; full-scale count: 4000 or $8000 \mathrm{cps}$ ).

High-temperature type thermomechanical analyzer, Rigaku Denki (the specimen was heated at $10^{\circ} \mathrm{C}$. $\mathrm{min}^{-1}$ in air and calibrated using a standard fused silica sample).

Autostrain, Yasuda Seiki No. 216YZ-500-1-PC Model (load application rate: $0.5 \mathrm{~mm} \cdot \mathrm{min}^{-1}$, span: $10 \mathrm{~mm}$ or $20 \mathrm{~mm}$ ).

Scanning electron microscope, Hitachi S-430 Model (acceleration voltage: $25 \mathrm{kV}$; the fracture surface of the specimen was polished and coated with a thin film of gold).

\section{Results and discussion}

3.1 Thermal behaviour and physical properties of glasses

The glasses were brownish black in color due to the titanium ions of lower valency. The glass bar and the glass-ceramics obtained from Glass- 1 are shown in Fig. 1. From the density of $\mathrm{Li}_{2} \mathrm{O}$ (or $\mathrm{MgO}, \mathrm{CaO}$ )$\mathrm{TiO}_{2}-\mathrm{P}_{2} \mathrm{O}_{5}$ glasses with $30 \mathrm{~mol} \% \mathrm{P}_{2} \mathrm{O}_{5},{ }^{2}$ the compositions of the glasses appear to be not appreciably different from those before melting, if sufficient preheating is used as in the present work.

Figure 2 shows the DTA curves of the obtained glasses. The exothermic reactions observed at 680 to $820^{\circ} \mathrm{C}$ are due to the crystallization of glasses. No endothermic effects owing to the melting of crystalline phases were observed up to $1000^{\circ} \mathrm{C}$. The glass-ceramics obtained from these glasses may be expected to be excellent in resistance to heating.

The physical properties of both glasses are given in Table 1. The densities are higher than those of $\mathrm{Li}_{2} \mathrm{O}$ (or $\mathrm{MgO}$ ) $-\mathrm{TiO}_{2}-\mathrm{P}_{2} \mathrm{O}_{5}$ glasses ${ }^{2)}$ already reported and the thermal expansion coefficients are lower than those of various soda-lime glasses. ${ }^{16)}$ These

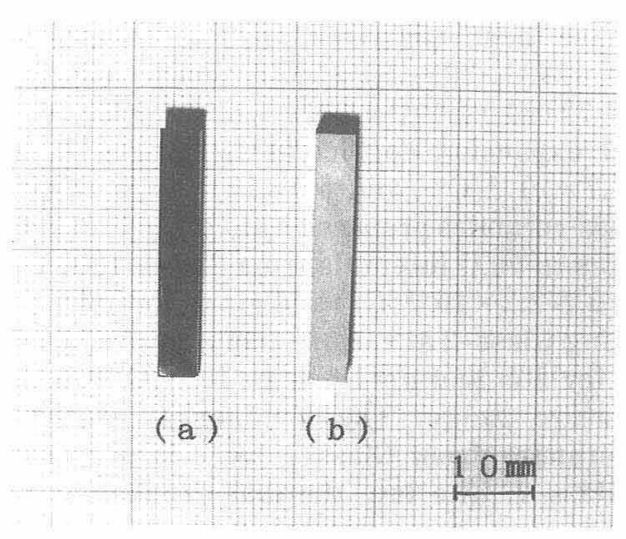

Fig. 1. Photograph of (a) Glass-1 and (b) glass-ceramics prepared from Glass-1.

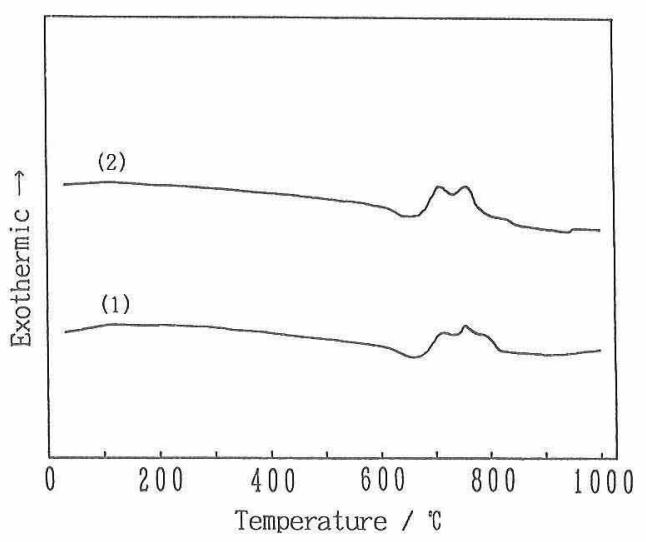

Fig. 2. DTA curves of (1) Glass-1 and (2) Glass-2.

(1) Glass-1: $\left(3 \mathrm{Na}_{2} \mathrm{O} \cdot 67 \mathrm{TiO}_{2} \cdot 30 \mathrm{P}_{2} \mathrm{O}_{5}\right)+5 \mathrm{SiO}_{2}(\mathrm{~mol} \%)$,

(2) Glass-2: $\left(3 \mathrm{Na}_{2} \mathrm{O} \cdot 72 \mathrm{TiO}_{2} \cdot 25 \mathrm{P}_{2} \mathrm{O}_{5}\right)+5 \mathrm{SiO}_{2}(\mathrm{~mol} \%)$.

Table 1. Physical Properties of Glass-1 and Glass-2

\begin{tabular}{llll}
\hline Glass & $\mathrm{Tg} / \mathrm{\tau}$ & $\rho / \mathrm{g} \cdot \mathrm{cm}^{-3}$ & $\alpha / \mathrm{q}^{-1}$ \\
\hline Glass-1 & 645 & 2.97 & $7.7 \times 10^{-6}$ \\
Glass-2 & 635 & 3.05 & $6.9 \times 10^{-6}$ \\
\hline
\end{tabular}


results suggest that the structures of the glasses are extremely stable, although each contains $\mathrm{P}_{2} \mathrm{O}_{5}$ as the main component. In the case of the alkali aluminophosphate glasses containing less than 50 mol\% of $\mathrm{P}_{2} \mathrm{O}_{5}$, the phosphate ion species in the glasses with the highest $\mathrm{Al}_{2} \mathrm{O}_{3}$ content are composed of the $\mathrm{PO}_{4}{ }^{3-}$ ion. ${ }^{17)}$ In addition, in the richest $\mathrm{TiO}_{2}$ glasses of $\mathrm{NaPO}_{3}-\mathrm{TiO}_{2}$ system, no more $\mathrm{P}-\mathrm{O}-\mathrm{P}$ bridges exist and the most probable configuration of the skeleton is $\mathrm{TiO}_{6}-\mathrm{PO}_{4}-\mathrm{TiO}_{6}$ polyhedra sharing either corners or edges. ${ }^{18)}$ Since very large amounts of $\mathrm{TiO}_{2}$ are incorporated into the glasses of this work and the $\mathrm{Na}_{2} \mathrm{O}$ content is very small, the glasses consist of essentially the - Ti-O-Ti- linkages of $\mathrm{TiO}_{6}$ octahedra and the $\mathrm{PO}_{4}{ }^{3-}$ ions. These facts appear to be responsible for the higher densities and the low thermal expansions of these glasses.

3.2 Crystalline phases in glass-ceramics

The crystalline phases produced from Glass- 1 during heating at 800 to $1050^{\circ} \mathrm{C}$ are shown in Fig. 3 and those from Glass -2 at 850 to $1100^{\circ} \mathrm{C}$ in Fig. 4. In Glass-1, a $\mathrm{NaTi}_{2}\left(\mathrm{PO}_{4}\right)_{3}$-like phase, of which the diffraction lines were shifted slightly from those of $\mathrm{NaTi}_{2}\left(\mathrm{PO}_{4}\right)_{3}$, were produced at 800 to $1050^{\circ} \mathrm{C}, \mathrm{TiO}_{2}$ (anatase) at 800 to $950^{\circ} \mathrm{C}, \mathrm{TiP}_{2} \mathrm{O}_{7}$ at $950^{\circ} \mathrm{C}$, and (TiO) ${ }_{2} \mathrm{P}_{2} \mathrm{O}_{7}$ was formed by reaction of $\mathrm{TiO}_{2}$ and $\mathrm{TiP}_{2} \mathrm{O}_{7}$ at 1000 to $1050^{\circ} \mathrm{C}$. In Glass-2, $\mathrm{NaTi}_{2}\left(\mathrm{PO}_{4}\right)_{3^{-}}$ like phase and $\mathrm{TiO}_{2}$ (anatase) were produced at 850 to $1100^{\circ} \mathrm{C}, \mathrm{TiP}_{2} \mathrm{O}_{7}$ was produced at $950^{\circ} \mathrm{C}$, and ( TiO) ${ }_{2} \mathrm{P}_{2} \mathrm{O}_{7}$ at 900 to $1100^{\circ} \mathrm{C}$. In the glass-ceramics prepared from Glass $-2, \mathrm{TiO}_{2}$ was formed over the

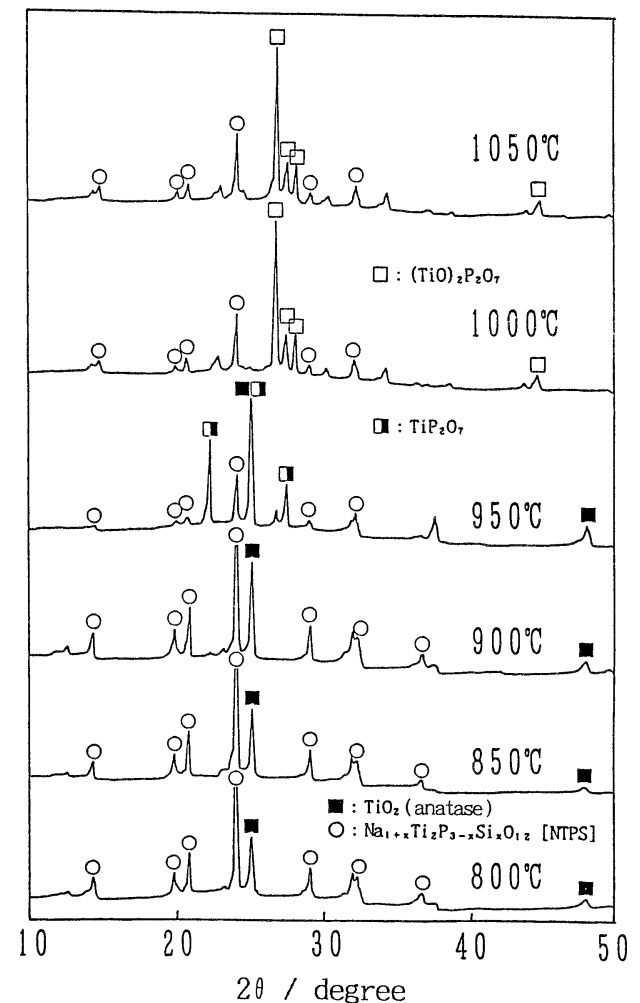

Fig. 3. XRD patterns of crystalline phases in the glass-ceramics prepared from Glass-1 at various temperatures.

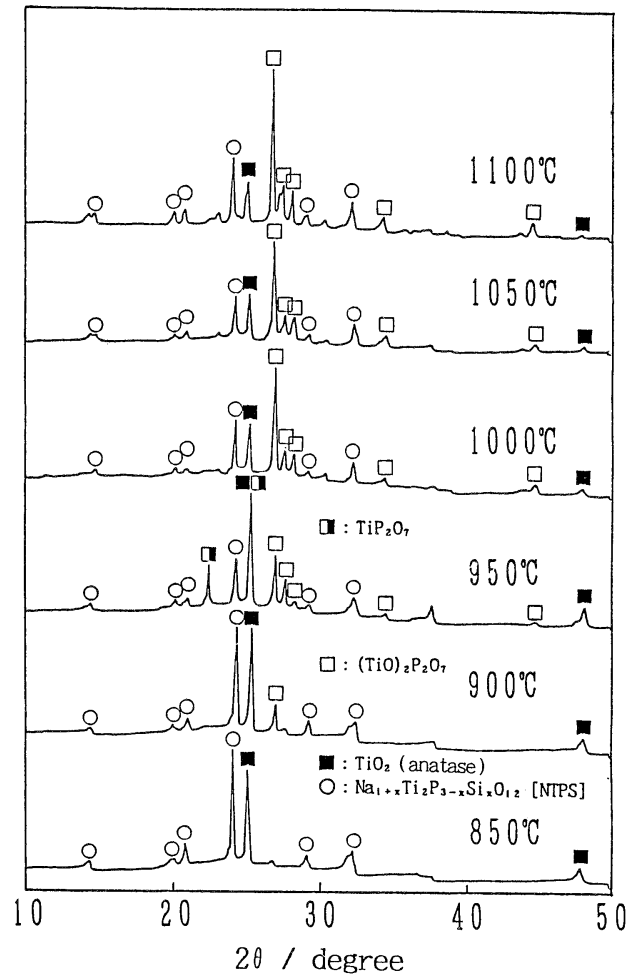

Fig. 4. XRD patterns of crystalline phases in the glass-ceramics prepared from Glass-2 at various temperatures.

temperature range from 850 to $1100^{\circ} \mathrm{C}$. The temperature at which $(\mathrm{TiO}){ }_{2} \mathrm{P}_{2} \mathrm{O}_{7}$ was formed was higher in Glass-1 than in Glass-2. These facts suggest that the structual differences between the two glass-ceramics are due to a higher $\mathrm{TiO}_{2}$ content in Glass-2 than in Glass -1 .

The $\mathrm{NaTi}_{2}\left(\mathrm{PO}_{4}\right)_{3}$-like phase seems to be the solid solution of $\mathrm{NaTi}_{2}\left(\mathrm{PO}_{4}\right)_{3}$ and $\mathrm{Si}^{4+}$, namely $\mathrm{Na}_{1+x}$ $\mathrm{Ti}_{2} \mathrm{P}_{3-x} \mathrm{Si}_{x} \mathrm{O}_{12}$ (NTPS). The lattice parameters of NTPS decreased slightly in $a$-axis $(0.0033 \AA$ in glassceramics from Glass- $1,0.0075 \AA$ in glass-ceramics from Glass-2) and increased greatly in $c$-axis $(0.3351 \AA$ in glass-ceramics from Glass- $1,0.2909 \AA$ in glass-ceramics from Glass-2) compared to those (a-axis: $8.4876 \AA, \quad c$-axis: $21.8008 \AA)$ of $\mathrm{NaTi}_{2}$ $\left(\mathrm{PO}_{4}\right)_{3} \cdot{ }^{15)}$

\subsection{Properties of glass-ceramics}

The thermal expansion curves as a function of temperature for the five kinds of glass-ceramics prepared from Glass -1 and for the three kinds from Glass -2 are given in Fig. 5 and Fig. 6, respectively. Table 2 and Table 3 show the thermal expansion coefficients from 30 to $600^{\circ} \mathrm{C}$ of the same specimens. The thermal expansion coefficients of these glass-ceramics are comparable to or lower than those of $\mathrm{Zr}(\mathbb{N})$ or $\mathrm{Ti}(\mathbb{N})$-containing double phosphate ceramics so far reported. ${ }^{7)-12)}$ In particular, the thermal expansion coefficient of the glass-ceramics obtained by heating Glass -1 at $1000^{\circ} \mathrm{C}$ for $30 \mathrm{~h}\left(\alpha=0.7 \times 10^{-6}\right.$ ${ }^{\circ} \mathrm{C}^{-1}$ ) and those by heating Glass -2 at 900 or $1100^{\circ} \mathrm{C}$ for $30 \mathrm{~h}\left(\alpha=1.6 \times 10^{-7}{ }^{\circ} \mathrm{C}^{-1}\right.$ and $2.2 \times 10^{-7}{ }^{\circ} \mathrm{C}^{-1}$, 


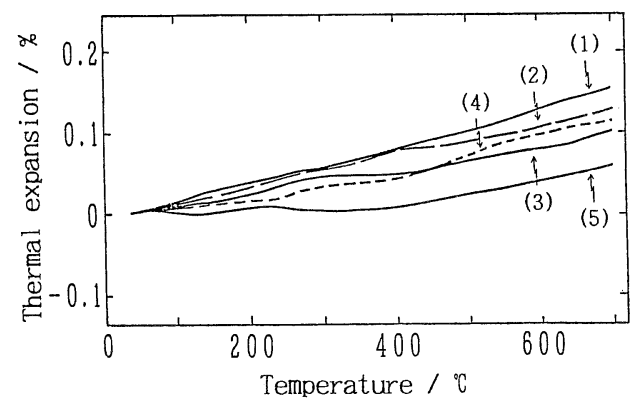

Fig. 5. Thermal expansion curves of glass-ceramics prepared from Glass -1 at various temperatures.

(1) $800^{\circ} \mathrm{C}$, (2) $850^{\circ} \mathrm{C}$, (3) $900^{\circ} \mathrm{C}$, (4) $950^{\circ} \mathrm{C}$, (5) $1000^{\circ} \mathrm{C}$.

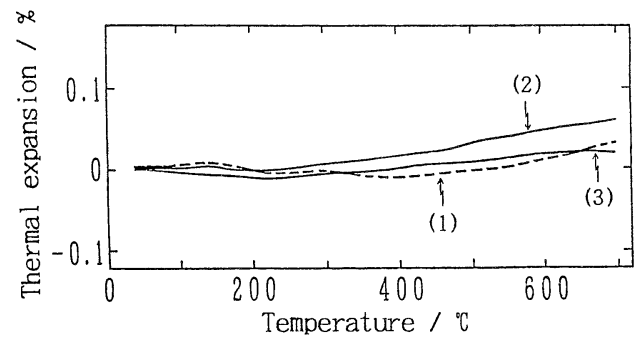

Fig. 6. Thermal expansion curves of glass-ceramics prepared from Glass -2 at various temperatures.

(1) $900^{\circ} \mathrm{C},(2) 1000^{\circ} \mathrm{C},(3) 1100^{\circ} \mathrm{C}$

Table 2. Thermal Expansion Coefficients $(\alpha)$ of $30-600^{\circ} \mathrm{C}$ for Glass-Ceramics Prepared from Glass -1 at Various Temperatures (1) $800^{\circ} \mathrm{C},(2) 850^{\circ} \mathrm{C},(3) 900^{\circ} \mathrm{C}$, (4) $950^{\circ} \mathrm{C}$, (5) $1000^{\circ} \mathrm{C}$

\begin{tabular}{cc}
\hline Glass-ceramics & $\alpha / q^{-1}$ \\
\hline$(1)$ & $2.2 \times 10^{-8}$ \\
$(2)$ & $1.9 \times 10^{-8}$ \\
$(3)$ & $1.4 \times 10^{-8}$ \\
$(4)$ & $1.7 \times 10^{-8}$ \\
$(5)$ & $0.7 \times 10^{-8}$
\end{tabular}

Table 3. Thermal Expansion Coefficients $(\alpha)$ of $30-600^{\circ} \mathrm{C}$ for Glass-Ceramics Prepared from Glass-2 at Various Temperatures (1) $900^{\circ} \mathrm{C},(2) 1000^{\circ} \mathrm{C},(3) 1100^{\circ} \mathrm{C}$

\begin{tabular}{cc}
\hline Glass-ceramics & $a / \mathrm{T}^{-1}$ \\
\hline$(1)$ & $1.6 \times 10^{-7}$ \\
$(2)$ & $8.4 \times 10^{-7}$ \\
$(3)$ & $2.2 \times 10^{-7}$ \\
\hline
\end{tabular}

respectively) are lower than those of the double phosphate ceramics. In the crystalline phases formed, $\mathrm{TiP}_{2} \mathrm{O}_{7}$ has a larger thermal expansion coefficient,

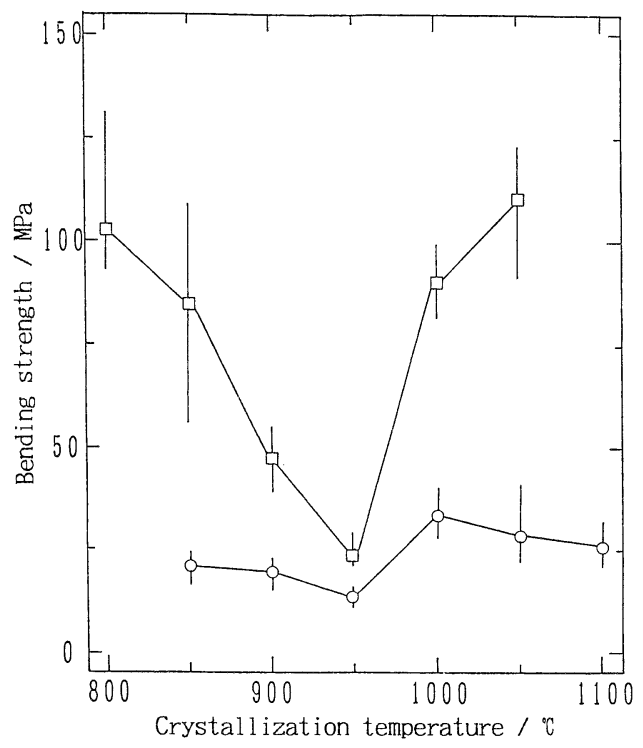

Fig. 7. Relations between bending strengths of glass-ceramics and temperatures for crystallizations of Glass -1 and Glass -2 .

$\square$ glass-ceramics prepared from Glass-1,

$\bigcirc$ glass-ceramics prepared from Glass- 2 .

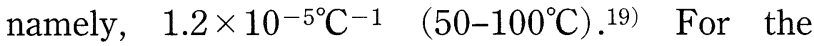
NTPS a lower thermal expansion may be expected, because it is a solid solution of low thermal expansion materials, $\mathrm{NaTi}_{2}\left(\mathrm{PO}_{4}\right)_{3}$ and $\mathrm{Si}^{4+}$. In addition, since the $\mathrm{TiO}_{2}$ and the $(\mathrm{TiO})_{2} \mathrm{P}_{2} \mathrm{O}_{7}$ were produced over a wide range of temperature during heating of glasses, these compounds also appear to contribute to a lowering in the thermal expansion of glass-ceramics. This fact is particularly obvious in the glass ceramics prepared from Glass-2.

Figure 7 shows the relations between the bending strengths of glass-ceramics and the temperatures for crystallizations of Glass -1 and Glass -2 . The bending strengths of the glass-ceramics prepared from Glass -1 were larger than those from Glass-2. Those of glass-ceramics prepared from Glass- 1 at 800 and $1100^{\circ} \mathrm{C}$ were larger than $100 \mathrm{MPa}$ and that at $1000^{\circ} \mathrm{C}$ was $91 \mathrm{MPa}$. In the case of the glass-ceramics prepared from Glass -1 at $950^{\circ} \mathrm{C}$, however, the bending strength had the lowest value: $25 \mathrm{MPa}$. According to the SEM photographs for the fracture surfaces of glass-ceramics shown in Figs. 8(a) -8 (d), the glassceramics prepared from Glass -1 at $800^{\circ} \mathrm{C}$ (a) were characterized by the uniform and dense structure consisting of fine particles, whereas the glass-ceramics prepared at $950^{\circ} \mathrm{C}$ (b) consisted of larger particles and in the structure many cracks existed. Such a microstructure was observed in the glass-ceramics prepared from Glass -2 at $1000^{\circ} \mathrm{C}$ (d). The decrease of bending strength in the glass-ceramics prepared from Glass -1 at $1000^{\circ} \mathrm{C}$ is due to the development of particles (c). The great decrease of the strength in the glass-ceramics prepared from Glass -1 at $950^{\circ} \mathrm{C}$ appears to be due to the occurrence of cracks caused by the formation of $\mathrm{TiP}_{2} \mathrm{O}_{7}$ at this temperature, be- 

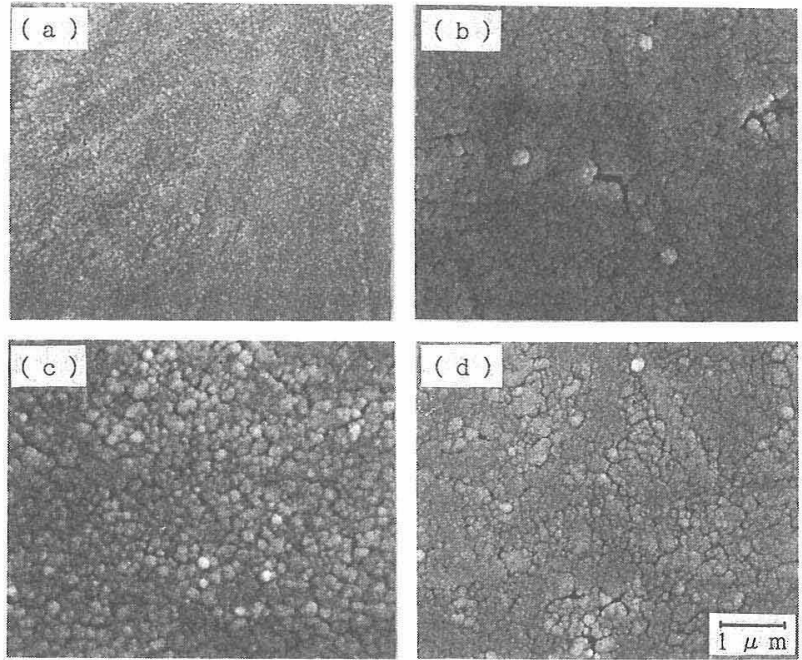

Fig. 8. SEM images for fracture surfaces of glass-ceramics. (a) prepared from Glass -1 at $800^{\circ} \mathrm{C}$,

(b) prepared from Glass -1 at $950^{\circ} \mathrm{C}$,

(c) prepared from Glass -1 at $1000^{\circ} \mathrm{C}$,

(d) prepared from Glass -2 at $1000^{\circ} \mathrm{C}$.

cause the same phenomenon is observed in the crystallization of Glass-2 (Fig. 4) and the bending strength of the glass-ceramics prepared from Glass2 at $950^{\circ} \mathrm{C}$ (Fig. 7 ).

\section{Conclusion}

Phosphate glasses with large amounts of $\mathrm{TiO}_{2}$ have been prepared in the compositions of $\left(3 \mathrm{Na}_{2} \mathrm{O}\right.$. $\left.67 \mathrm{TiO}_{2} \cdot 30 \mathrm{P}_{2} \mathrm{O}_{5}\right)+5 \mathrm{SiO}_{2}(\mathrm{~mol} \%)$ (Glass-1) and (3 $\left.\mathrm{Na}_{2} \mathrm{O} \cdot 72 \mathrm{TiO}_{2} \cdot 25 \mathrm{P}_{2} \mathrm{O}_{5}\right)+5 \mathrm{SiO}_{2}(\mathrm{~mol} \%) \quad$ (Glass-2). The thermal expansion coefficients $(\alpha)$ of the glassceramics prepared from these glasses were comparable to or lower than those of $\mathrm{Zr}(\mathbb{N})$ or $\mathrm{Ti}(\mathbb{N})$-containing double phosphate ceramics so far reported. In particular, the glass-ceramics obtained by heating
Glass -1 at $1000^{\circ} \mathrm{C}$ for $30 \mathrm{~h}$ showed $\alpha=0.7 \times 10^{-6}{ }^{\circ} \mathrm{C}^{-1}$ and the bending strength of this glass-ceramics was $91 \mathrm{MPa}$. The low thermal expansions of these glassceramics were due to the formation of $\mathrm{Na}_{1+x} \mathrm{Ti}_{2} \mathrm{P}_{3-x}$ $\mathrm{Si}_{x} \mathrm{O}_{12}, \mathrm{TiO}_{2}$ and $(\mathrm{TiO}){ }_{2} \mathrm{P}_{2} \mathrm{O}_{7}$.

\section{References}

1) A. Kishioka, M. Haba and M. Amagasa, Bull. Chem. Soc. Jpn., 47, 2493-96 (1974).

2) A. Kishioka, Bull. Chem. Soc. Jpn., 51, 2559-61 (1978).

3) H. Hosono, Z. Zhang and Y. Abe, J. Am. Ceram. Soc., 72, 1587-90 (1989).

4) H. Hosono and Y. Abe, J. Electrochem. Soc., 137, 3149-51 (1990).

5) H. Hosono and Y. Abe, J. Am. Ceram. Soc., 75, 2862-64 (1992).

6) H. Hosono, Y. Sakai and Y. Abe, J. Non-Cryst. Solids, 139, 90-92 (1992).

7) D. K. Agrawal and R. Roy, J. Mater. Sci., 20, 4617-23 (1985).

8) T. Oota and I. Yamai, J. Am. Ceram. Soc., 69, 1-6 (1986).

9) C. Delmas and A. Nadiri, Solid State Ionics, 28-30, 419-23 (1988).

10) T. Oota, P. Jin and I. Yamai, J. Mater. Sci., 24, 4239-45 (1989).

11) S. Y. Limaye, D. K. Agrawal and R. Roy, J. Mater. Sci., 26, 93-98 (1991).

12) Y. Miyamoto, A. Kishioka, K. Itatani and M. Kinoshita, Seramikkusu Ronbunshi, 99, 676-80 (1991).

13) Y. Miyamoto, H. Takahashi, M. Kinoshita and A. Kishioka, J. Ceram. Soc. Japan, 100, 1025-31 (1992).

14) T. Hanada, T. Aikawa and N. Soga, J. Am. Ceram. Soc., 67, 52-56 (1984).

15) M. P. Carrasco, M. C. Guillem and J. Alamo, Mater. Res. Bull., 27, 603-10 (1992).

16) S. Sakka, Ed., "Garasu no Jiten", Asakura Shoten, Tokyo (1988) p. 367.

17) A. Kishioka, Bull. Chem. Soc. Jpn., 50, 2088-92 (1977).

18) C. Rousselot, E. El Rhess, J. P. Malugani, R. Mercier, M. F. Mercier and A. Kishioka, Solid State Ionics, 58, 71-76 (1992).

19) D. E. Harrison and F. A. Hummel, J. Am. Ceram. Soc., 42, 487-90 (1959). 